\title{
How Elections Change the Way Citizens View the Political System: Campaigns, Media Effects and Electoral Outcomes in Comparative Perspective
}

\author{
SUSAN A. BANDUCCI AND JEFFREY A. KARP*
}

\begin{abstract}
Attitudes towards the political system have often been assumed to be stable attributes that are not easily influenced by short-term forces. We examine the extent to which attention to media coverage, campaign activity and electoral outcomes can mobilize support for the political system in the context of an election campaign. Using pre-election and post-election survey panels from the United States, Britain and New Zealand, we find only small shifts in aggregate measures of system support. However, we find that there are significant shifts in system support at the individual level that can be explained by status as election winners, attention to the media, particularly serious news coverage and economic perceptions. The results have implications for the debate over measures of system support such as trust, cynicism and efficacy.
\end{abstract}

Elections are primarily viewed as an opportunity for citizens to influence political leaders, but they also serve as a means by which parties and candidates can mobilize support for democratic processes. As the most visible link between elected representatives and citizens, elections can serve an important function in the process of building and maintaining support for the political system. Democratic theory assumes a relationship between election participation and the legitimacy of the political system - fairly conducted and regular elections create system legitimacy. In theory, democratic elections should make citizens feel better about the institutions and the political process. Indeed, a link can be found between electoral participation and the duration and maintenance of political efficacy and regime support. ${ }^{1}$

These questions about the ability of elections to alter perceptions of the political system are particularly important given declining voter turnout and political participation, increasing cynicism about politics and a growing lack of trust in politicians and public institutions that has been well documented in the United States and elsewhere. ${ }^{2}$ Since the

* Department of Political Science, University of Twente. Names are listed alphabetically, authorship is equal. Funding for Susan Banducci was provided by the European Union's Fifth Framework Programme. Funding for Jeffrey Karp was provided by the Netherlands Organization for Scientific Research (NWO). An earlier version of this article was prepared for delivery at the Regional Conference of the World Association for Public Opinion Research, Universidad de Navarra, Pamplona, Spain, November 2000. Some early results of this project were presented (with Richard Clucas) at the joint conference of the World Association for Public Opinion Research and the American Association for Public Opinion Research, Portland, Oregon, May 2000.

1 Steven E. Finkel, 'The Effect of Participation on Political Efficacy and Political Support: Evidence from a West German Panel', Journal of Politics, 49 (1987), 441-64; Steven E. Finkel, 'Reciprocal Effects of Participation and Political Efficacy’, American Journal of Political Science, 29 (1985), 891-913.

${ }^{2}$ In the United States, see Paul Abramson, Political Attitudes in America: Formation and Change (San Francisco: W. H. Freeman, 1983); Stephen C. Craig, The Malevolent Leaders: Popular Discontent in America (Boulder, Colo.: Westview Press, 1993). Outside the United States, see Russell J. Dalton, 'System Support in 
mid-1970s, scholars have disagreed over the potential causes of this decline as well as its implications. Researchers in the tradition of the Michigan school have assumed that feelings of trust and efficacy are orientations towards the political system that develop early in life. Supporting this view, Iyengar concludes from an analysis of panel data in the United States that 'external efficacy' (what we refer to as efficacy) is not a response to the current political situation but is a 'firmly embedded' attitude related to evaluations of regime responsiveness. ${ }^{3}$ More recent studies suggest the potential for short-term change, particularly during election campaigns. ${ }^{4}$ That campaigns should influence evaluations of the political systems seems reasonable; for the average citizen, an election campaign provides the single most 'compelling incentive to think about government' ${ }^{5}$ Even those who normally find politics uninteresting may become engaged during a spirited campaign.

In order to contribute towards a democratic theory, it is important to understand what aspects of campaigns have the potential to mobilize or demobilize regime support. For example, given that most information about the conduct of the campaign is gained via the media, how does the coverage influence changes in the way people view the political system? Other aspects of campaigns to consider are the role of party mobilization and electoral outcomes. Those scholars who have examined political efficacy and regime support also suggest that the electoral context may influence the relationship between campaigns and political efficacy but this question has not been examined from a comparative perspective. ${ }^{6}$ In the following analysis we examine aspects of election campaigns that influence support for the political system in three countries: the United States, New Zealand and Britain. Each country in the study provides a different institutional and campaign context that may interact with campaign factors influencing system support.

\section{CAMPAIGNS AND SYSTEM SUPPORT}

Past studies on the relationship between elections and system support have tended to focus on the effects of participation, both voting and campaign activity. Steven Finkel has examined the longer-term effects of campaign participation using panel studies in the United States and Germany in separate studies and he finds that campaign participation and voting tend to have positive influences on regime support and political efficacy. ${ }^{7}$

(F'note continued)

Advanced Industrial Democracies', in Pippa Norris, ed., Critical Citizens: Global Support for Democratic Governance (New York: Oxford University Press, 1999), pp. 57-77. For an alternative view, see Hans-Dieter Klingemann and Dieter Fuchs, eds, Citizens and the State: A Changing Relationship? (Oxford: Oxford University Press, 1995).

${ }^{3}$ Shanto Iyengar, 'Subjective Political Efficacy as a Measure of Diffuse Support', Public Opinion Quarterly, 44 (1980), 249-56.

${ }^{4}$ Harold D. Clarke and Alan C. Acock, 'National Elections and Political Attitudes: The Case of Political Efficacy', British Journal of Political Science, 19 (1989), 551-62. See also Wendy M. Rahn, John Brehm and Neil Carlson, 'National Elections as Institutions for Generating Social Capital', in Theda Skocpol and Morris P. Fiorina, eds, Civic Engagement in American Democracy (Washington, DC: Brookings Institution, 1999), pp. $111-60$.

5 Thomas Riker, 'Why Negative Campaigning is Rational' (paper presented at the Annual Meeting of the American Political Science Association, Atlanta, Ga., 1989).

${ }^{6}$ Clarke and Acock, 'National Elections and Political Attitudes'; Rahn, Brehm and Carlson, 'National Elections as Institutions for Generating Social Capital'.

${ }^{7}$ Finkel, 'The Effect of Participation on Political Efficacy and Political Support'; Finkel, 'Reciprocal Effects of Participation and Political Efficacy'. 
However, other evidence suggests that short-term shifts in system support and efficacy during a campaign are not necessarily due to voting and campaign participation, leading some to conclude that elections themselves and not political participation influence short-term shifts in evaluations of the responsiveness of the political system. ${ }^{8}$ In the following section we examine several aspects of campaigns that could contribute to mobilizing or demobilizing support for the political system. By reviewing earlier studies examining how system support can be influenced by the media, electoral outcomes and party mobilization, we develop several expectations about how election campaigns influence short-term changes in support for the political system. We also examine how the institutional context and the electoral system can influence the relationship between elections and system support. We then construct a model that examines these questions during election campaigns in three countries.

\section{Media Effects}

A number of studies contend that the way the media choose to cover politics contributes to growing cynicism and declining civic engagement. ${ }^{9}$ Coverage of politics in both the United States and elsewhere appears to be increasingly dominated by a focus on political actors and scandal. For example, in Sweden, politicians are portrayed more negatively today than in the 1950 s, especially in broadcast media. ${ }^{10}$ The argument follows that this negative coverage is reflected in an increasingly cynical electorate. The media's increasing tendency to frame issues in terms of political strategy may also contribute to a decline in system support. ${ }^{11}$ Another potential impact has to do with the medium itself. Television, in particular, has been pegged as a culprit. Brehm and Rahn find that simply watching television diminishes civic engagement. ${ }^{12}$ The negative effect may be related to time-displacement and television viewing. The more time citizens spend watching television, the less time they have to engage in civic-minded activities. ${ }^{13}$ However, this latter effect does not necessarily suggest that time displacement can alter attitudes towards the political system.

Yet, other evidence shows that television and media exposure mobilizes and engages the electorate in the political process. Norris finds a high correlation between television viewing and political knowledge suggesting a 'virtuous circle' where repeated exposure increases levels of information. ${ }^{14}$ Looking specifically at trust and confidence in

${ }^{8}$ Clarke and Acock, 'National Elections and Political Attitudes'. See also Rahn, Brehm and Carlson, 'National Elections as Institutions for Generating Social Capital'.

${ }^{9}$ Robert D. Putnam, 'Tuning In, Tuning Out: The Strange Disappearance of Social Capital in America', Political Science and Politics, 28 (1995), 664-83; Michael J. Robinson, 'Public Affairs Television and the Growth of Political Malaise: The Case of the "The Selling of the Pentagon", American Political Science Review, 70 (1976), 409-32. For a counter argument and evidence, see Eric M. Uslaner, 'Social Capital, Television, and the "Mean World": Trust, Optimism, and Civic Participation', Political Psychology, 19 (1998), 441-67.

10 Soren Holmberg, 'Down and Down We Go: Political Trust in Sweden', in Norris, ed., Critical Citizens, pp. 103-222, at p. 119.

11 Thomas E. Patterson, Out of Order (New York: Alfred A. Knopf, 1993); Joseph N. Cappella and Kathleen H. Jamieson, Spiral of Cynicism: The Press and the Public Good (New York: Oxford University Press, 1997).

${ }^{12}$ John Brehm and Wendy M. Rahn, 'Individual-level Evidence for the Causes and Consequences of Social Capital', American Journal of Political Science, 41 (1998), 999-1023.

${ }_{13}^{13}$ Putnam, 'Tuning In, Tuning Out'.

14 Pippa Norris, A Virtuous Circle: Political Communications in Postindustrial Societies (Cambridge: Cambridge University Press, 2000). 
democratic institutions, media use has little impact on perceptions of institutional trust and confidence but this impact tends to be positive. ${ }^{15}$ Thus, according to this line of research, television and other media, rather than hastening the decline of Western civilization, contribute to a heightened level of civic engagement.

One solution to the debate over malaise versus mobilization is to consider the content of the media or the specific medium that delivers the content. In other words, the influential factor is not how much television citizens watch but the quality of the content. For example, quality news coverage may mobilize while sensationalist tabloid television may turn off the electorate. Recent research lends support to the differing effects interpretation. For example, using data from the 1996 British Social Attitudes Survey, Newton finds that regular reading of a broadsheet strongly and positively influences engagement while regular television viewing is weakly correlated with engagement. ${ }^{16}$

Given the negative tone of most political talk radio, particularly in the United States, one might expect talk radio to be associated with more negative attitudes about the political system. ${ }^{17}$ However, the participatory nature of political talk radio, where listeners are encouraged to phone in and express political attitudes and comment on current political events, may contribute to enhanced feelings of political efficacy. ${ }^{18}$ On the whole, political talk radio listeners tend to be conservative, are more interested in all types of news and rate the other news media poorly. ${ }^{19}$ Therefore, if this portrait of the talk radio listener is accurate and system support is influenced by interest in politics, attention to political talk radio may have a positive influence on system support.

Today, most citizens' experiences of an election campaign are through the media. Studies that specifically examine media effects on civic engagement or system support during a campaign have mixed results. Research based on the 1992 US election suggests that attention to campaign news coverage on television reduced political trust. ${ }^{20}$ In Britain, however, an analysis of trust, efficacy and knowledge during the 1997 parliamentary campaign shows no evidence of a short-term media demobilization effect. ${ }^{21}$ In a study of

15 Michael Pfau, Patricia Moy and Lee Ann Kahlor, 'Media Use and Public Confidence in Democratic Institutions', Journal of Broadcasting and Electronic Media, 43 (1999), 137-58; Stephen E. Bennett, Staci L. Rhine, Richard S. Flickinger and Linda L. Bennett, "“Video Malaise” Revisited: Public Trust in the Media and Government', Harvard International Journal of Press/Politics, 4 (1999), 8-23.

${ }^{16}$ Kenneth Newton, 'Mass Media Effects: Mobilization or Media Malaise?' British Journal of Political Science, 29 (1999), 577-99.

${ }^{17}$ Michael Pfau, Kathleen Kendall, Tom Reichert, Susan A. Hellweg, Waipang Lee, Kyle James Tusing and Theodore O. Proisise, 'The Influence of Talk Radio on Confidence in Democratic Institutions', Journalism and Mass Communication Quarterly, 75 (1998), 730-45. Despite the growth in national and local British talk radio, the negative characterization may not apply due to a required party balance in election coverage, the neutral role of news presenters and a history of public broadcasting (see Richard Davis and John Curtice, 'Speaking for the Public: Representation and Audience Participation during the 1997 British General Election Campaign', Harvard International Journal of Press/Politics, 5 (2000), 62-77; and Martin Harrison, 'Politics on the Air', in David Butler and Dennis Kavanagh, eds, The British General Election of 1997 (Basingstoke, Hants.: Macmillan, 1997), pp. 133-55.

${ }^{18}$ David Weaver, 'Media Agenda-Setting and Elections - Voter Involvement or Alienation', Political Communication, 11 (1994), 347-56.

19 Media Studies Center, 'Profile of Political Talk Radio Listeners' [News advisory, 1997]. Retrieved 19 June 1999 from http://www.mediastudies.org/talksur.html.

${ }^{20}$ Steven Chan, 'Effect of Attention to Campaign Coverage on Political Trust', International Journal of Public Opinion Research, 9 (1997), 286-96.

${ }^{21}$ Pippa Norris, John Curtice, David Sanders, Margaret Scammell and Holli A. Semetko, On Message: Communicating the Campaign (London: Sage Publications, 1999). 
the 1998 Dutch parliamentary election, Aarts and Semetko found that watching public television news programmes had a positive influence on political involvement while commercial television viewing had a negative impact. ${ }^{22}$

We can also separate media from more general campaign effects. Although most of the electorate gathers information about the campaign from media coverage, party advertisements and pamphlets also reach voters. Research on negative political advertising suggests that 'attack ads', particularly 'mudslinging', demobilizes the electorate. ${ }^{23}$ Reported exposure to negative advertising, which is becoming more prevalent in political campaigns, has also been found to be negatively correlated to political efficacy and trust in government. ${ }^{24}$ Yet when parties and candidates make personal contact with voters, it is assumed to have a positive influence. Personal contact during the campaign is assumed to be one of the primary means of mobilization. ${ }^{25}$ When parties contact voters it is assumed to enhance citizens' belief in their own political efficacy.

\section{Electoral Outcomes and Institutions}

Campaign or election outcomes may also influence attitudes towards the political system. The 'Home Team' hypothesis suggests that system support is dependent on partisan control of the government. ${ }^{26}$ Support for a winning party leads to increases in efficacy and trust. ${ }^{27}$ In a recent analysis of the 1972 and 1996 US elections, Anderson and LoTempio find that those voting for the presidential winner were significantly more trusting. ${ }^{28}$ However, they do not examine the effect of winning and losing in the context of other campaign effects nor do they examine actual changes in levels of support for the political system.

The institutional context in which losing and winning takes place is also important. The electoral system may help to mediate the differences between winners and losers. Systems that distort the translation of votes into seats may serve to alienate segments of the electorate who are not fairly represented. ${ }^{29}$ Dissatisfaction may grow over time among

22 Kees Aarts and Holli A. Semetko, 'The Divided Electorate: Effects of the Campaign and Media Use on Political Involvement' (paper for the workshop 'Do Campaigns Matter? The Political Consequences of Modern Electioneering', ECPR Joint Sessions, April 2000).

${ }^{23}$ Stephen Ansolabehere, Shanto Iyengar, Adam Simon and Nicholas Valentino, 'Does Attack Advertising Demobilize the Electorate?' American Political Science Review, 88 (1994), 829-38; Kim Fridkin Kahn and Patrick J. Kenney, 'Do Negative Campaigns Mobilize or Suppress Turnout? Clarifying the Relationship between Negativity and Participation', American Political Science Review, 93 (1999), 877-89. For a different conclusion on the demobilizing effects of attack advertising, see Steven E. Finkel and J. G. Geer, 'A Spot Check: Casting Doubt on the Demobilizing Effect of Attack Advertising', American Journal of Political Science, 42 (1998), 573-95.

${ }^{24}$ Stephen Ansolabehere and Shanto Iyengar, Going Negative: How Political Advertisements Shrink and Polarize the Electorate (New York: Free Press, 1995).

${ }^{25}$ Steven J. Rosenstone and John M. Hansen, Mobilization, Participation, and Democracy in America (New York: Macmillan, 1993).

${ }^{26}$ Holmberg, 'Down and Down We Go'; Pippa Norris, 'Institutional Explanations for System Support', in Norris, ed., Critical Citizens, pp. 188-203.

${ }^{27}$ Clarke and Acock, 'National Elections and Political Attitudes'; Harold D. Clarke and Alan Kornberg, 'Do National Elections Affect Perceptions of MP Responsiveness: A Note on the Canadian Case', Legislative Studies Quarterly, 17 (1992), 183-204.

${ }^{28}$ Christopher J. Anderson and Andrew LoTempio, 'Winning, Losing and Political Trust in America', British Journal of Political Science, 32 (2002), 335-51.

29 Douglas Amy, Real Choices/New Voices: The Case for PR Elections in the United States (New York: Colombia University Press, 1993); Lani Guinier, The Tyranny of the Majority: Fundamental Fairness in Representative Democracy (New York: Free Press, 1994). 
those who do not have political representation or are continually in opposition. Proportional representation systems are assumed to enhance political participation because fewer votes are wasted. ${ }^{30}$ Consensual systems are also assumed to foster more positive attitudes towards the political system than majoritarian systems. ${ }^{31}$ Anderson and Guillory found in a study of eleven European democracies that political institutions mediated the relationship between a person's status as a political minority and her satisfaction with democracy. ${ }^{32}$ Those supporting parties that were not in government were more likely to be satisfied with democracy in 'consensual' systems. In majoritarian electoral systems persons who recall voting for the losing party were more dissatisfied. If these attitudes are based on winning and losing as Anderson and Guillory suggest, we would expect changes in system support from before to after a campaign to be greatest among losers in majoritarian electoral systems. We might also expect changes in government to enhance system support. Such outcomes may have a greater impact for winners who have been in opposition longer.

This review of the literature suggests that the following factors can affect changes in system support during a campaign: media exposure, campaign contact and electoral outcomes. Because these effects may be conditioned by the electoral system, a comparative approach across different electoral systems is useful. We first examine the extent of variations in system support during election campaigns. Secondly, we examine how election campaigns are related to changes in levels of system support at the individual level. We expect that some factors such as supporting a winning party, being contacted by a politician and paying attention to 'serious' campaign coverage such as in newspapers will positively influence an individual's level of system support. By contrast, support for election losers and paying attention to campaign media when coverage is negative will tend to demobilize system support. We also expect that the effect of being an election winner or loser should be greatest in majoritarian systems.

\section{DATA: PRE-ELECTION AND POST-ELECTION STUDIES}

Most of the studies demonstrating a decline in support for democratic institutions emphasize aggregate changes in system support using cross-sectional data collected over a couple of decades. Individual level analyses typically rely on a single cross-section and explain static levels of system support. ${ }^{33}$ We do not know from these studies if changes are uniform across sub-populations and whether variables that explain the static level of system support also explain changes in system support over time. Media effects are also difficult to demonstrate with a cross-sectional design because one cannot determine the

${ }^{30}$ Mark N. Franklin, 'Electoral Participation' in Lawrence LeDuc, Richard G. Niemi and Pippa Norris, eds, Comparing Democracies: Elections and Voting in Global Perspective (Thousand Oaks, Calif.: Sage, 1996), pp. 214-33; Robert W. Jackman and Ross A. Miller, 'Voter Turnout in the Industrial Democracies During the 1980s', Comparative Political Studies, 27 (1995), 467-92; Jeffrey A. Karp and Susan A. Banducci, 'The Impact of Proportional Representation on Turnout: Evidence from New Zealand', Australian Journal of Political Science, 34 (1999), 363-78; G. Bingham Powell Jr, 'American Voter Turnout in Comparative Perspective', American Political Science Review, 80 (1986), 17-43.

31 Arend Lijphart, Patterns of Democracy: Government Forms and Performance in Thirty-Six Countries (New Haven: Yale University Press, 1999).

${ }^{32}$ Christopher J. Anderson and Christine A. Guillory, 'Political Institutions and Satisfaction with Democracy: A Cross-National Analysis of Consensus and Majoritarian Systems', American Political Science Review, 91 (1997), 66-81.

${ }^{33}$ Iyengar, 'Subjective Political Efficacy as a Measure of Diffuse Support'. 
direction of causality. For example, positive associations between media exposure and political attitudes can be interpreted as having a positive impact, ${ }^{34}$ but such relationships may also be due to more trusting individuals paying greater attention to the media. To overcome these problems we employ a panel design where our variables of interest are measured before and after the campaign. This permits a more rigorous test of causal relations than is possible with cross-sectional data.

The panel data we use come from the 1999 New Zealand Election Study (NZES), the 1996 American National Election Study (ANES) and the 1997 British Election Study (BES). In these elections, voters elected a new centre-left government in New Zealand and Britain, while there was no change in partisan control of the presidency or Congress in the United States. Aside from differences in election outcomes, the sample of countries under study also has the advantage of having significant variation in institutional design. While Britain and the United States have electoral systems based on plurality (or first-past-thepost) rules, New Zealand has a mixed electoral system based on proportional representation. In our sample of countries, New Zealand is the most consensual system while Britain is the most majoritarian. ${ }^{35}$

Because of the built-in panel between the pre-election and post-election of the ANES, NZES and BES studies, we can compare change at the individual level from pre-election to post-election. ${ }^{36}$ The pre-election component of the NZES and the ANES also allow cross-sectional comparisons to be made during the campaign. The 1999 NZES includes a pre-election rolling cross-section which is increasingly becoming a part of national election studies (Canada 1993, 1998; New Zealand 1996, 1999; the Netherlands 1998). The design of the pre-election rolling cross-section involves interviewing a random sample of respondents each day of the election campaign. ${ }^{37}$ While the 1999 ANES survey does not take advantage of the rolling cross-section design, interviewing took place over a sixty-three day period prior to the election allowing one to compare responses over time. ${ }^{38}$

The main dependent variables are questions about attitudes towards democracy, voting and representatives. From the NZES, we use three questions that were asked in both the pre-election and post-election studies. The first question measures satisfaction with how democracy is working in New Zealand. The second question asks respondents whether they agree or disagree with the statement, 'My vote counts in elections.' The third question asks respondents to agree or disagree with the statement, 'MPs are out of touch.' From the

${ }^{34}$ See for example, Norris, A Virtuous Circle.

35 Lijphart, Patterns of Democracy.

36 The 1997 BES contains three pre-election waves and a post-election wave. The first wave of the study was administered one year prior to the campaign while the second and third waves were administered approximately one month and one week, respectively, prior to the election. Our analysis is restricted to the second pre-election wave as our focus is on short-term change and our measures of interest were not included in the last pre-election wave. For more detail on the 1997 BES, see Norris et al., On Message, pp. 187-97.

${ }^{37}$ In 1999, the NZES interviewed approximately ninety respondents each day from 18 October to 25 November. During the pre-election interview respondents were asked if they would be willing to participate in the post election survey. Of the initial 3,409 respondents who agreed to a long-form telephone campaign survey, 3,137 agreed to do a post-election survey. Of these, 2,060 actually returned a post-election survey. For more detail on the 1999 NZES see Jack Vowles, Peter Aimer, Jeffrey Karp, Susan Banducci, Raymond Miller and Ann Sullivan, Proportional Representation on Trial: The 1999 New Zealand General Election and the Fate of MMP (Auckland: Auckland University Press, 2002).

${ }^{38}$ For more detail on the 1996 ANES study, see Steven J. Rosenstone, Donald R. Kinder and Warren E. Miller, National Election Studies, 1996: Pre-and Post-Election Study [dataset]. 3rd release (Ann Arbor: University of Michigan, Center for Political Studies [producer and distributor]). 
ANES pre-election and post-election studies, we use 'trust government' and 'no say about what government does'. From the BES, we use 'MPs lose touch' and 'parties only interested in votes.' These two questions were asked in the first and second waves of the 1997 BES campaign panel and in the post-election study. The satisfaction with democracy and trust questions are intended to measure overall support for the political system while the other questions refer more specifically to elections and representatives respectively. ${ }^{39}$ According to Weatherford, 'no say', 'parties only interested in votes' and 'MPs lose (are out of) touch' are evaluations of the 'representational procedures' in democratic countries. ${ }^{40}$ The 'no say' and 'parties only interested in votes' items reflect whether or not parties and elections are able to make elected officials accountable to the people while 'MPs out of touch' indicates the responsiveness of politicians to the public. The 'vote counts' question (not used by Weatherford) fits into the former category. The 'trust government' item from the ANES and NZES data measures fairness of the political process and is an indicator of overall government performance. ${ }^{41}$

Our independent variables measure media attention during the campaign and party contact as specific campaign effects. For this analysis, we rely on media attention rather than media exposure. In other words, we use questions asking respondents whether they paid attention to the campaign on different media rather than asking how many days they usually watch television or read newspapers. Media attention questions were asked in more similar formats across the three election studies than media exposure questions. ${ }^{42}$ Party contact is measured in the post-election survey in New Zealand and the United States. In Britain, no indicator of party or candidate contact is available.

We use intended vote to capture a respondent's status as winner or loser. A voter may be a winner before the election, i.e. support the incumbent government, but become a loser if that party does not form part of the post-election government. Therefore, we use a series of dummy variables indicating the party of the respondent's intended vote.

A large body of literature shows that the state of the economy influences vote choice and support for the incumbent government. ${ }^{43}$ Economic evaluations also have been linked

39 There is considerable debate over the meaning of the satisfaction with democracy question. As with the other measures of system support, there is disagreement as to whether to question measures system support or specific support, a combination of both or neither (see Damarys Canache, Jeffery J. Mondak and Mitchell A. Seligson, 'Meaning and Measurement in Cross-national Research on Satisfaction with Democracy' (paper presented at the Joint Conference of the World Association and American Association for Public Opinion Research, Portland, Oregon, May 2000). Other research finds that measures of trust are related to both specific and diffuse system support and that low levels of trust cause dissatisfaction with political leaders (Mark J. Hetherington, 'The Political Relevance of Political Trust', American Political Science Review, 92 (1998), 791-808). Because part of our analysis seeks to answer this question by examining how susceptible to short-term change these items are, we are confident in using these indicators.

${ }^{40}$ M. Stephen Weatherford, 'Measuring Political Legitimacy', American Political Science Review, 86 (1992), 149-66.

41 Weatherford, 'Measuring Political Legitimacy'.

42 No media exposure questions were asked in the NZES. As a test of whether the exposure measures yielded different results in the United States and Britain (where both attention and exposure questions were used), we substituted exposure to newspapers and nightly television news for the media attention variables. The exposure variables had no significant impact in either country and the significance levels of the other independent variables were not altered. Although the 1997 BES distinguishes between exposure to different television broadcasts, it does not make the same distinction between attention to different television broadcasts. Therefore, we proceed by examining attention to television in Britain without making distinctions between different channels.

${ }^{43}$ For summaries of the literature on economic influences on vote choice and support for the incumbent government, see Michael Lewis-Beck, Economics and Elections: The Major Western Democracies (Ann Arbor: 
to changes in system support in the United States. ${ }^{44}$ In an analysis based on the 1990-91 World Values Survey, McAllister concludes that economic conditions are more important than social factors in explaining confidence in democratic institutions. ${ }^{45}$ Therefore, we control for these effects by using an evaluation of the national economic situation over the past year as an indicator of economic performance. In the ANES and NZES we use the date of the pre-election interview to pick up campaign effects that are not captured by media exposure and campaign contact. ${ }^{46}$ Age, gender, education and minority status are used to represent social and demographic characteristics that might affect an individual's level of political efficacy. Finally, attention to different media during the campaign may be an indicator for the interest in the campaign. In order to make the tests for media effects even more conservative, we control for the effects of interest in the campaign. ${ }^{47}$ Exact question wording and coding for dependent and independent variables is given in the Appendix to this article.

The effect of attention to the media should depend to some extent on the coverage provided by media outlets. Reports of media content during the 1996 US presidential election agree that media coverage tended to be slightly more positive towards Bill Clinton but there tended to be a balance between positive and negative stories. ${ }^{48}$ According to the same reports, the focus tended to be on character, strategy and issues; even though 38 per cent of the stories were focused on the horserace, the remaining stories were character or issue related. Political advertisements, by contrast, were generally negative. ${ }^{49}$ According to Norris et al., British coverage of the 1997 campaign dominated the news throughout the month prior to the election with the conduct of the campaign, the parties, opinion polls as the most important topics. ${ }^{50}$ By their accounts, most of the campaign coverage on BBC, ITN and in newspapers was devoted to the daily activities of the leaders on the campaign trail, electoral strategy and party tactics, while approximately a third of the coverage was devoted to substantive policy issues. Given Labour's comfortable lead, television news and

(F'note continued)

University of Michigan Press, 1988); Kristen Monroe, Presidential Popularity and the Economy (New York: Praeger, 1984) and Electoral Studies, 19 (2000), Special Issue on economic voting.

${ }^{44}$ M. Stephen Weatherford, 'How Does Government Performance Influence System Support?' Political Behavior, 9 (1987), 5-28.

${ }^{45}$ Ian McAllister, 'The Economic Performance of Governments', in Norris, ed., Critical Citizens, pp. 188-203.

${ }^{46}$ In the BES, the three waves were conducted during short interview periods of approximately a week. Therefore, analysis over the weeks of the campaign is not appropriate and no measure of time is used in the multivariate models.

${ }^{47}$ We did not include a measure of interest in the campaign in the case of Britain. The question was available but was only asked in the first wave of the panel design and the questions we used in the analysis come from the second and final waves of the panel. If we include interest in the model, our sample size drops to 433 due to attrition. We estimated the model with the 433 cases and the results are similar. We feel that the reduction in error achieved by the additional cases outweighs the need to have strictly comparable models in this instance.

${ }^{48}$ Based on an analysis of media content from March until November, 45.5 per cent of stories had a negative tone towards Clinton or Bob Dole (David Domke et al., 'New Media, Candidates and Issues, and Public Opinion in the 1996 Presidential Campaign', Journalism and Mass Communication Quarterly, 74 (1997), 718-37). See also Robert E. Denton, 'Communication Variables and Dynamics of the 1996 Presidential Campaign', in Robert E. Denton, ed., The 1996 Presidential Campaign: A Communication Perspective (Westport, Conn.: Praeger, 1998), pp. $1-50$, at pp. $45-6$.

${ }_{49}$ During the general election period, 61 per cent of Dole's advertisements had a negative tone while 71 per cent of Clinton's had a negative focus (Linda L. Kaid, 'Videostyle and the Effects of the 1996 Presidential Campaign Advertising', in Denton, ed., The 1996 Presidential Campaign: A Communication Perspective, pp. $143-59$, at p. 149.

${ }^{50}$ Norris et al., On Message, pp. 73-8. 


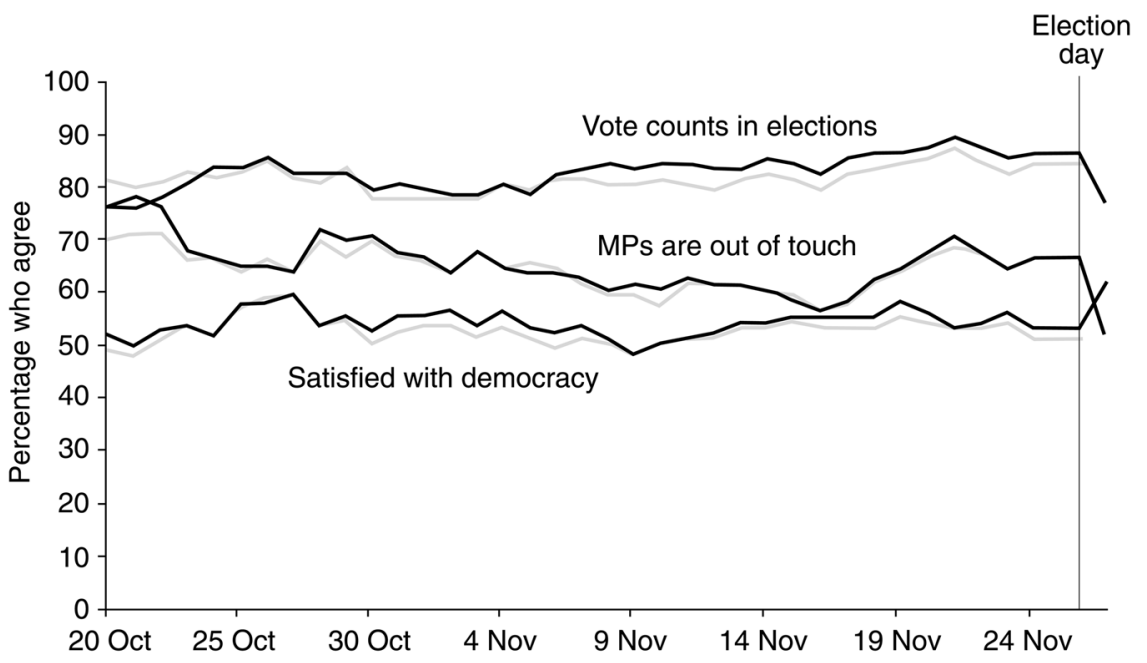

Fig. 1. New Zealand election campaign, 1999

Note: Five-day moving average. Lighter lines indicate those who did not return a post-election booklet.

newspaper coverage of opinion polls and the horse race declined substantially from 1992, comprising just 10 per cent of the television coverage and 13 per cent of the main subject front page news stories. In New Zealand, campaign events dominated the election coverage while less than a third of the television news stories covered the 'horse race'. Approximately a third of the stories had a negative tone regarding the leader of the major centre-right party with minimal negative coverage of the other major party leader. ${ }^{51}$ While US campaign coverage appeared to place somewhat more emphasis on the horse race, media coverage of the campaigns in all three countries appeared to be balanced, leading us to expect positive media effects. However, given the use of negative advertising in the US campaign, exposure to campaign advertisements leads us to expect a negative effect. ${ }^{52}$ We also expect a negative effect for those exposed to talk radio, given its critical tone. ${ }^{53}$

\section{RESULTS}

\section{System Support over the Campaign}

We first examine the extent to which measures of system support vary over the course of the campaign. Figures 1 and 2 show the pattern of system support over the course of the campaign in New Zealand and the United States. ${ }^{54}$ The data from the 1999 NZES reported

51 Susan Banducci and Jack Vowles, 'Elections, Citizens, and the Media', in Vowles et al., Proportional Representation on Trial, pp. 34-49.

52 Only in the United States are survey questions available to test for the influence of campaign advertisements.

53 Unfortunately, we are unable to test this hypothesis in Britain since the question was not asked.

${ }^{54}$ For the NZES data, we use centred five-day moving averages. The centred moving average for a particular day is calculated using the percentage from the day plus the percentages from the two days prior and later. Trust and efficacy questions asked in the pre-election phase were repeated in the post-election mail survey. Due to the use of a split sample during the pre-election interview, sample sizes are smaller for each individual question. The sample size for each average is approximately 450. For the ANES data, we use centred nine-day moving averages yielding an approximate sample size of 250 . 


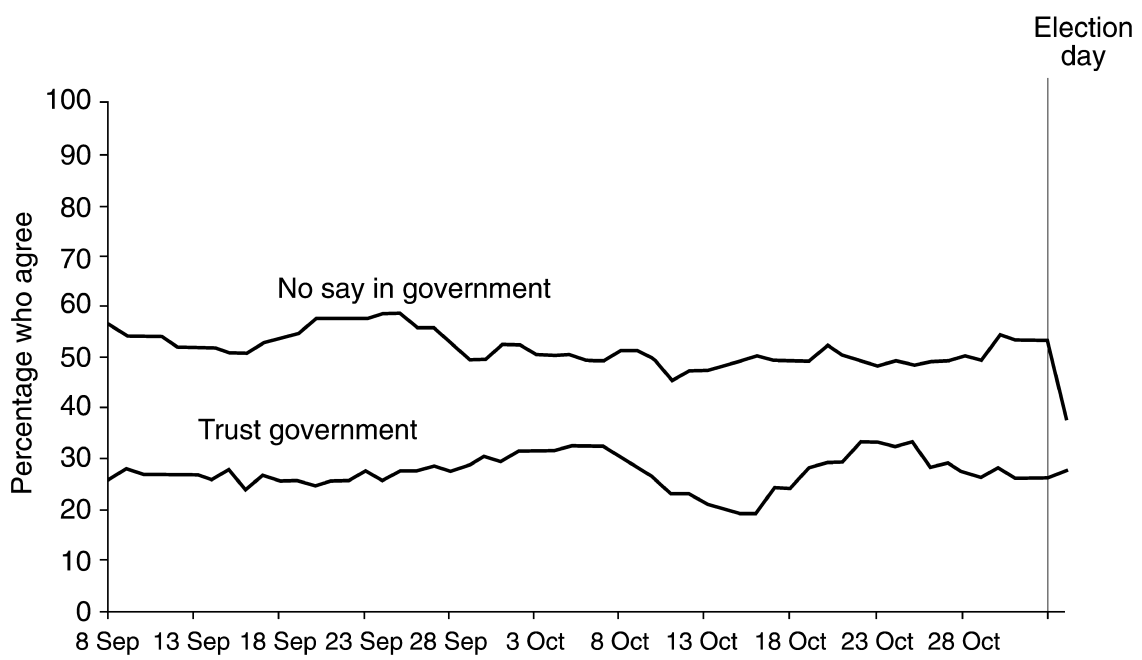

Fig. 2. United States election campaign, 1996

Note: Nine-day moving average.

in Figure 1 are the proportion of respondents who are very satisfied or satisfied with how democracy works, the proportion who agree with the vote counts statement and the proportion who agree that MPs are out of touch. Agreement with the 'vote counts' statement denotes satisfaction, while agreement with the 'MPs out of touch' statement indicates dissatisfaction. In Figure 1, which represents the New Zealand campaign, each of the indictors of system support are represented by two lines. The darker line indicates those respondents who participated in both waves while the lighter line indicates those who only participated in the pre-election wave. We show these two lines in order to test whether or not a bias is present in the post-election sample. Those who participated in the post-election sample may be more politically involved and satisfied with politics and thus more likely to return a survey about politics. Overall, there appears to be little difference between the two samples. The one exception is at the beginning of the survey period, but these differences show that the participants in the pre-election and post-election surveys were slightly more cynical on two of the three indictors.

The trends in system support evident in both figures show few dramatic changes over the course of the campaign. With a number of parties and candidates courting their votes, a few more New Zealand citizens recognize that their votes count as the campaign progresses. This same courting should make MPs appear more responsive to voters. During the first five weeks of the campaign this appears to be the case. However, the trend reverses in the final two weeks of the campaign. Nevertheless, there is about a 10 per cent decrease over the entire campaign. While there is some variation in satisfaction with democracy, the percentage satisfied at the beginning of the campaign is very similar to that at the end of the campaign just prior to the election. In the United States, the proportion who agree (strongly or otherwise) that they have no say in what government does is also stable over the course of the campaign. On trust, while there is some variation over the campaign, the proportion trusting government is about the same at the end of the campaign as it was at the start. 
More substantial changes in attitudes are evident between the pre-election and post-election observations. In the United States, although there is no change in trust in government, there is a 15 per cent decrease in the percentage believing that they have no say in what government does between the last pre-election observation and the post-election sample. Similarly, in New Zealand, the evaluation of the responsiveness of MPs improves after the election; the number agreeing that MPs are out of touch drops to 53 per cent from 67 per cent in the pre-election observation. ${ }^{55}$ Consistent with an increase in responsiveness, the percentage of people who are satisfied with democracy also jumps after the elections. ${ }^{56}$ However, the proportion of those saying their vote counts drops indicating lower efficacy. This decline could be explained by a loss of efficacy among supporters of the parties that did not form part of the new government. We investigate this below.

TABLE 1 Individual Change in System Support from Pre-election to Post-election

\begin{tabular}{lccc}
\hline \hline & $\begin{array}{c}\text { Increase in } \\
\text { system } \\
\text { support }\end{array}$ & No change & $\begin{array}{c}\text { Decrease in } \\
\text { system } \\
\text { support }\end{array}$ \\
\hline New Zealand & & & \\
$\quad$ Satisfaction with democracy (\%) & 29.6 & 55.3 & 15.8 \\
$\quad$ Vote counts (\%) & 7.0 & 79.8 & 13.2 \\
$\quad$ MPs (in) touch (\%) & 22.9 & 63.6 & 13.6 \\
United States & 15.0 & 73.9 & 11.1 \\
$\quad$ Trust government (\%) & 31.7 & 44.5 & 23.8 \\
$\quad$ Say in government (\%) & & & \\
Britain & 38.3 & 45.6 & 16.0 \\
$\quad$ Parties (not) interested only in votes (\%) & 32.2 & 46.8 & 21.1 \\
$\quad$ MPs (in) touch (\%) & & & \\
\hline \hline
\end{tabular}

Note: Some rows do not sum to 100.0 due to rounding.

Source: 1996 American National Election Study; 1997 British Election Study; and 1999 New Zealand Election Study.

While the data presented in Figures 1 and 2 suggest that electoral outcomes affected system support, we can more accurately assess individual change from pre-election to post-election with the panel data. Table 1 shows these individual changes from before to after the election in all three countries and lists the proportion of respondents who had an increase in system support, those who had no change in system support and the proportion

\footnotetext{
55 The pre-election study was conducted by phone and respondents were only given an agree, disagree or neutral response option. In the post-election mail-back survey, respondents were given the options: agree strongly, agree, neutral, disagree or disagree strongly. We have collapsed the agree and strongly agree categories from the post-election survey to make the responses comparable between the pre-election and post-election surveys.

56 The post-election version of this question differs slightly from the pre-election version. In the pre-election survey no neutral category is offered. If the lack of the neutral category in the pre-election poll was causing the change in responses, we would expect the percentage satisfied or very satisfied to decrease as respondents would spread themselves across five response categories rather than four and the satisfied categories would have fewer respondents in them.
} 
of respondents who had a decrease in system support. All questions representing the dependent variables have been scaled so that high values indicate greater satisfaction, efficacy and trust. With the exception of efficacy in New Zealand, the proportion of respondents increasing in system support is greater than the proportion experiencing a decrease in system support. In New Zealand, the share of those increasing in satisfaction with democracy is twice as high as those having a decrease in satisfaction. A similar result is found in Britain on the item measuring cynicism about parties. The results from the analysis of individual change are generally consistent with the analysis of aggregate shifts displayed in Figures 1 and 2 indicating an overall increase in system support. Of course, the highest proportion of respondents had no change at all in levels of system support. Yet, despite the lack of dramatic shifts in the aggregate measures of system support, the results in Table 1 do suggest that the campaign has the potential to influence changes in levels of system support at the individual level.

\section{Multivariate Models}

Further to investigate changes at the individual level, we turn to a multivariate analysis. Two models are estimated in each country. The first model examines initial levels of system support while the second model estimates changes in system support. Using ordered probit, both models are estimated in order to determine which factors affect initial levels of system support versus those factors that affect changes in support over the campaign. In the second model, post-election attitudes are estimated as a function of pre-election attitudes. In other words, our models do not use the difference between pre-election and post-election system support as the dependent variable. Rather, change is modelled by controlling for pre-election attitudes in the model predicting post-election attitudes. By estimating post-election attitudes while controlling for the respondent's pre-election attitudes, we can evaluate how some group's opinions shifted over time relative to other reference groups. These lagged endogenous variable specifications are well suited for examining change in panel data, and are a conservative test for opinion change since they can be biased against rejecting the null hypotheses. ${ }^{57}$ Ordered probit models are generally used when the scale of the dependent variable is discrete and ordered and when the distance between the points on the scale are not known (for example, when the distance between 1 and 2 is not equal to the distance between 2 and 3). To illustrate, an ordered probit model predicting no system support after the election (for example, post-election trust in government $=0$ ) where each of the independent variables are identified by group would appear as follows:

$$
\begin{aligned}
& \operatorname{Prob}\left(\text { Trust }_{\mathrm{t}+1}=0\right)=\mathrm{F}\left(\text { Trust }_{t i} \beta_{1}+\text { Interest }_{i} \beta_{2}+\text { Media Attention }_{i} \beta_{3}+\text { Campaign }_{i} \beta_{4}\right. \\
& \text { Winner/Loser } \beta_{5}+\text { Policy }_{\mathrm{i}} \beta_{6}+\text { Socio-demo }_{i} \beta_{7}+\varepsilon_{i} \text { ) }
\end{aligned}
$$

where $\mathrm{F}$ indicates the cumulative normal density function. A model predicting higher levels of trust (trust $>0$ ) includes an additional parameter for the estimate of the threshold between the points on the scale for each category (for example, between 0.75 and 1).

The results from the multivariate analysis are reported in Tables $2 \mathrm{a}-\mathrm{c}$. To ease the interpretation of the probit coefficients in the lagged models, we also report probabilities for each of the significant coefficients in Table 3. These estimates represent the probability of change in system support from one category to another between pre-election and post-election (see Appendix for details). These estimates are calculated as change at the

${ }^{57}$ Gregory Markus, Analyzing Panel Data (Beverly Hills, Calif.: Sage, 1979). 


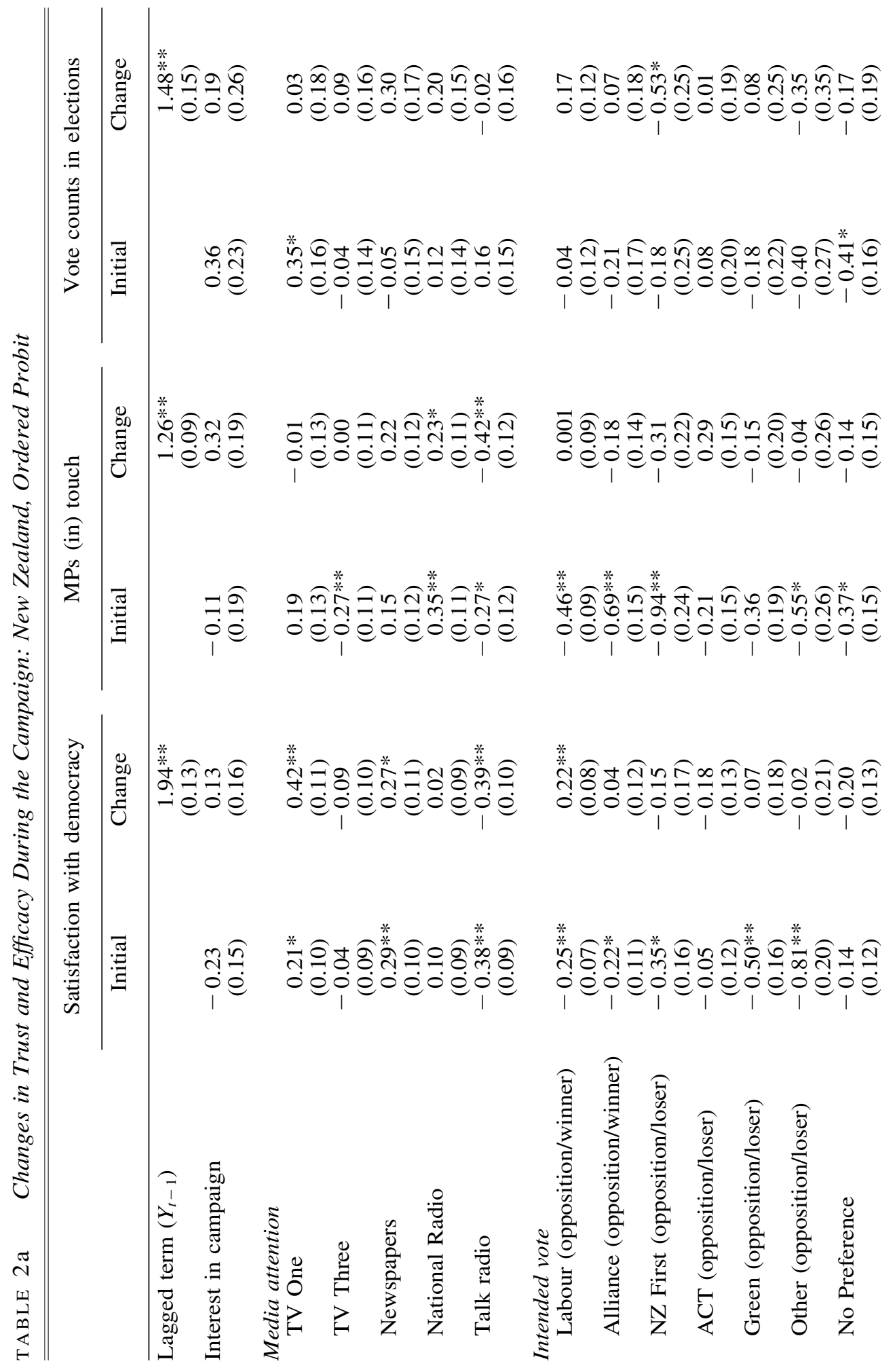




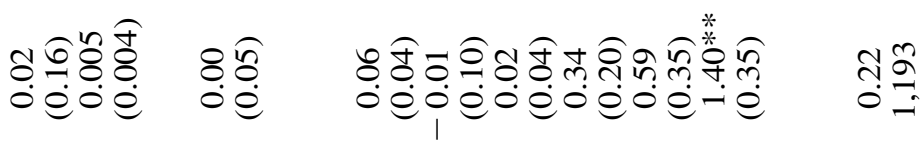

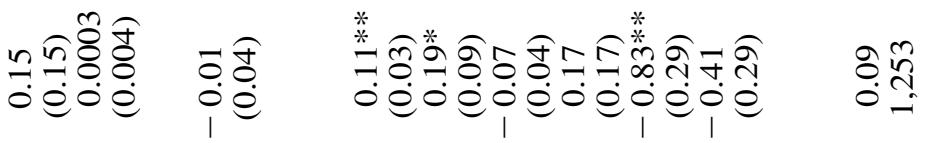

i

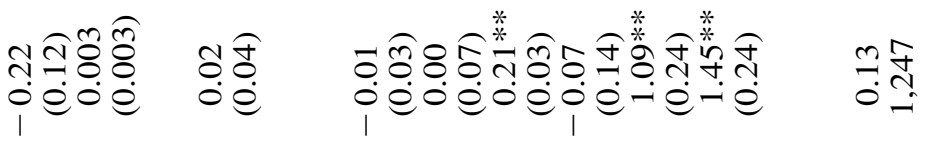

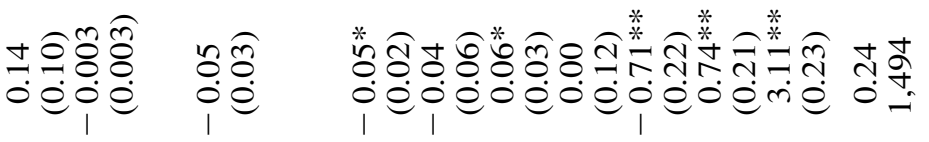

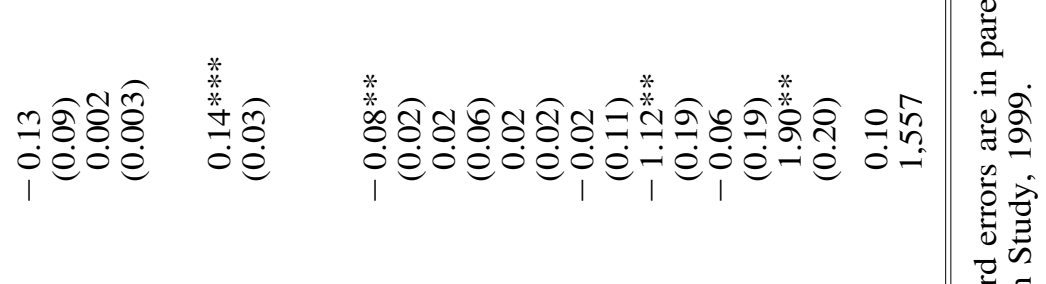

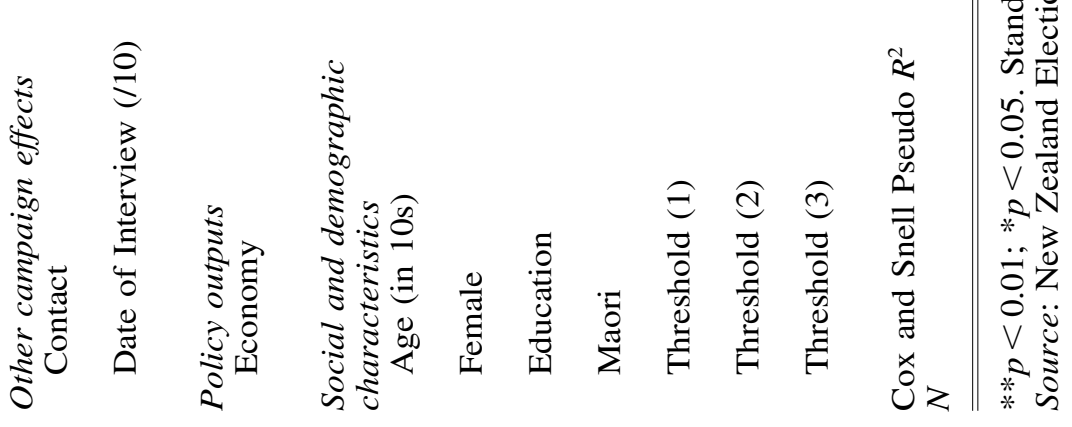


TABLE 2b Changes in Trust and Efficacy During the Campaign: United States, Ordered Probit

\begin{tabular}{|c|c|c|c|c|}
\hline & \multicolumn{2}{|c|}{ Trust government } & \multicolumn{2}{|c|}{ Say in government } \\
\hline & Initial & Change & Initial & Change \\
\hline Lagged term $\left(Y_{t-1}\right)$ & & $\begin{array}{l}1.99 * * \\
(0.14)\end{array}$ & & $\begin{array}{l}1.70 * * \\
(0.09)\end{array}$ \\
\hline Interest in campaign & $\begin{array}{c}-0.23 * \\
(0.11)\end{array}$ & $\begin{array}{r}-0.11 \\
(0.12)\end{array}$ & $\begin{array}{c}0.23 * \\
(0.09)\end{array}$ & $\begin{array}{c}0.09 \\
(0.10)\end{array}$ \\
\hline \multicolumn{5}{|l|}{ Media attention } \\
\hline Attention to national TV & $\begin{array}{c}0.07 \\
(0.13)\end{array}$ & $\begin{array}{c}0.25 \\
(0.14)\end{array}$ & $\begin{array}{c}0.12 \\
(0.10)\end{array}$ & $\begin{array}{r}-0.03 \\
(0.11)\end{array}$ \\
\hline Attention to local TV & $\begin{array}{c}0.30 * \\
(0.14)\end{array}$ & $\begin{array}{c}0.19 \\
(0.14)\end{array}$ & $\begin{array}{c}0.19 \\
(0.11)\end{array}$ & $\begin{array}{c}0.08 \\
(0.11)\end{array}$ \\
\hline Attention to newspapers & $\begin{array}{c}0.06 \\
(0.12)\end{array}$ & $\begin{array}{c}0.02 \\
(0.12)\end{array}$ & $\begin{array}{c}0.19^{*} \\
(0.09)\end{array}$ & $\begin{array}{c}0.13 \\
(0.10)\end{array}$ \\
\hline Saw TV advertisements & $\begin{array}{c}-0.31 * * \\
(0.08)\end{array}$ & $\begin{array}{r}-0.04 \\
(0.09)\end{array}$ & $\begin{array}{r}-1.14 * \\
(0.07)\end{array}$ & $\begin{array}{c}0.07 \\
(0.07)\end{array}$ \\
\hline Attention to talk radio & $\begin{array}{c}-0.21 \\
(0.13)\end{array}$ & $\begin{array}{c}0.03 \\
(0.13)\end{array}$ & $\begin{array}{c}0.08 \\
(0.10)\end{array}$ & $\begin{array}{c}0.20 \\
(0.11)\end{array}$ \\
\hline \multicolumn{5}{|l|}{ Intended vote } \\
\hline Democrat (incumbent/winner) & $\begin{array}{l}0.51 * * \\
(0.07)\end{array}$ & $\begin{array}{l}0.28 * * \\
(0.08)\end{array}$ & $\begin{array}{c}0.01 \\
(0.06)\end{array}$ & $\begin{array}{c}0.09 \\
(0.06)\end{array}$ \\
\hline Reform (opposition/loser) & $\begin{array}{r}-0.23 \\
(0.16)\end{array}$ & $\begin{array}{c}0.31^{*} \\
(0.15)\end{array}$ & $\begin{array}{c}-0.32 * \\
(0.11)\end{array}$ & $\begin{array}{r}-0.17 \\
(0.13)\end{array}$ \\
\hline No preference & $\begin{array}{c}-0.14 \\
(0.11)\end{array}$ & $\begin{array}{c}0.15 \\
(0.12)\end{array}$ & $\begin{array}{r}-0.23^{*} \\
(0.09)\end{array}$ & $\begin{array}{r}-0.21 * \\
(0.10)\end{array}$ \\
\hline \multicolumn{5}{|l|}{ Other campaign effects } \\
\hline Contact & $\begin{array}{c}0.03 \\
(0.08)\end{array}$ & $\begin{array}{c}0.02 \\
(0.08)\end{array}$ & $\begin{array}{c}0.03 \\
(0.06)\end{array}$ & $\begin{array}{c}0.13^{*} \\
(0.06)\end{array}$ \\
\hline Date of interview $(/ 10)$ & $\begin{array}{c}0.03 \\
(0.02)\end{array}$ & $\begin{array}{c}0.05^{*} \\
(0.02)\end{array}$ & $\begin{array}{c}0.01 \\
(0.02)\end{array}$ & $\begin{array}{c}0.01 \\
(0.02)\end{array}$ \\
\hline Policy outputs & & & & \\
\hline Economy & $\begin{array}{l}0.10^{* *} \\
(0.03)\end{array}$ & $\begin{array}{c}-0.01 \\
(0.03)\end{array}$ & $\begin{array}{l}0.07 * * \\
(0.03)\end{array}$ & $\begin{array}{c}0.04 \\
(0.03)\end{array}$ \\
\hline \multicolumn{5}{|l|}{ Characteristics } \\
\hline Age (in 10s) & $\begin{array}{l}0.08 * * \\
(0.02)\end{array}$ & $\begin{array}{r}-0.01 \\
(0.02)\end{array}$ & $\begin{array}{c}-0.04 * \\
(0.02)\end{array}$ & $\begin{array}{r}-0.03 \\
(0.02)\end{array}$ \\
\hline Female & $\begin{array}{r}-0.04 \\
(0.07)\end{array}$ & $\begin{array}{r}-0.12 \\
(0.07)\end{array}$ & $\begin{array}{c}0.03 \\
(0.05)\end{array}$ & $\begin{array}{r}-0.06 \\
(0.06)\end{array}$ \\
\hline Education & $\begin{array}{r}-0.01 \\
(0.02)\end{array}$ & $\begin{array}{c}-0.04 * \\
(0.02)\end{array}$ & $\begin{array}{c}0.11^{*} \\
(0.02)\end{array}$ & $\begin{array}{l}0.10 * * \\
(0.02)\end{array}$ \\
\hline Black & $\begin{array}{c}-0.14 \\
(0.10)\end{array}$ & $\begin{array}{c}-0.05 \\
(0.11)\end{array}$ & -0.08 & $\begin{array}{c}0.11 \\
(0.09)\end{array}$ \\
\hline Threshold (1) & $\begin{array}{l}1.36 * * \\
(0.22)\end{array}$ & $\begin{array}{l}0.95 * * \\
(0.24)\end{array}$ & $\begin{array}{r}-0.31 \\
(0.17)\end{array}$ & $\begin{array}{c}0.02 \\
(0.19)\end{array}$ \\
\hline Threshold (2) & $\begin{array}{l}2.84 * * \\
(0.23)\end{array}$ & $\begin{array}{l}2.84 * * \\
(0.26)\end{array}$ & $\begin{array}{l}0.77 * * \\
(0.17)\end{array}$ & $\begin{array}{l}1.23 * * \\
(0.20)\end{array}$ \\
\hline Threshold (3) & & & $\begin{array}{l}1.01 * * \\
(0.17)\end{array}$ & $\begin{array}{l}1.54 * * \\
(0.20)\end{array}$ \\
\hline Threshold (4) & & & $\begin{array}{l}1.93^{* *} \\
(0.18)\end{array}$ & $\begin{array}{l}2.91 * * \\
(0.20)\end{array}$ \\
\hline Cox and Snell Pseudo $R^{2}$ & 0.07 & 0.19 & 0.10 & 0.30 \\
\hline$N$ & 1,692 & 1,488 & 1,698 & 1,504 \\
\hline
\end{tabular}

$* * p<0.01 ; * p<0.05$. Standard errors are in parentheses.

Source: American National Election Study, 1996. 
TABLE 2c Changes in Trust and Efficacy During the Campaign: Britain, Ordered Probit

\begin{tabular}{|c|c|c|c|c|}
\hline & \multicolumn{2}{|c|}{ MPs (in) touch } & \multicolumn{2}{|c|}{$\begin{array}{l}\text { Parties (not) interested } \\
\text { only in votes }\end{array}$} \\
\hline & Initial & Change & Initial & Change \\
\hline Lagged term $\left(Y_{t-1}\right)$ & & $\begin{array}{l}1.49^{*} \\
(0.12)\end{array}$ & & $\begin{array}{l}1.80 * * \\
(0.12)\end{array}$ \\
\hline $\begin{array}{l}\text { Media attention } \\
\text { Attention to TV } \\
\text { Attention to newspapers }\end{array}$ & $\begin{array}{c}0.33^{* *} \\
(0.09) \\
0.27 * \\
(0.11)\end{array}$ & $\begin{array}{c}0.09 \\
(0.09) \\
0.15 \\
(0.11)\end{array}$ & $\begin{array}{c}0.33 * * \\
(0.09) \\
-0.09 \\
(0.11)\end{array}$ & $\begin{array}{c}0.20^{*} \\
(0.09) \\
0.26^{*} \\
(0.11)\end{array}$ \\
\hline $\begin{array}{l}\text { Intended vote } \\
\quad \text { Labour (opposition/winner) }\end{array}$ & $\begin{array}{r}-0.16^{*} \\
(0.07)\end{array}$ & $\begin{array}{c}0.25^{*} \\
(0.08)\end{array}$ & $\begin{array}{c}-0.12 \\
(0.07)\end{array}$ & $\begin{array}{l}0.57 * * \\
(0.08)\end{array}$ \\
\hline $\begin{array}{l}\text { Liberal Democrats (opposition/loser) } \\
\text { Other (opposition/loser) }\end{array}$ & $\begin{array}{l}-0.38 * * \\
(0.10) \\
-0.76 * *\end{array}$ & $\begin{array}{c}0.11 \\
(0.10) \\
-0.33 *\end{array}$ & $\begin{array}{l}-0.34 * * \\
(0.10) \\
-0.66 * *\end{array}$ & $\begin{array}{l}0.39 * * \\
(0.10) \\
-0.08\end{array}$ \\
\hline No preference & $\begin{array}{l}(0.13) \\
-0.32 * * \\
(0.09)\end{array}$ & $\begin{array}{c}(0.14) \\
-0.14 \\
(0.10)\end{array}$ & $\begin{array}{l}(0.13) \\
-0.30 * * \\
(0.10)\end{array}$ & $\begin{array}{c}(0.13) \\
0.02 \\
(0.10)\end{array}$ \\
\hline $\begin{array}{l}\text { Policy outputs } \\
\text { Economy }\end{array}$ & $\begin{array}{l}0.13^{* *} \\
(0.03)\end{array}$ & $\begin{array}{c}0.06 \\
(0.03)\end{array}$ & $\begin{array}{l}0.09 * * \\
(0.03)\end{array}$ & $\begin{array}{c}-0.029 \\
(0.03)\end{array}$ \\
\hline $\begin{array}{l}\text { Social and demographic characteristics } \\
\text { Age (in 10s) }\end{array}$ & $\begin{array}{c}-0.31 \\
(0.20)\end{array}$ & $\begin{array}{c}-0.52^{*} \\
(0.20)\end{array}$ & $\begin{array}{c}0.31 \\
(0.20)\end{array}$ & $\begin{array}{c}-0.37 * \\
(0.20)\end{array}$ \\
\hline Female & $\begin{array}{c}0.09 \\
(0.06)\end{array}$ & $\begin{array}{c}0.06 \\
(0.06)\end{array}$ & $\begin{array}{r}-0.01 \\
(0.09)\end{array}$ & $\begin{array}{l}0.15^{*} \\
(0.06)\end{array}$ \\
\hline Education & $\begin{array}{c}0.04 * \\
(0.02)\end{array}$ & $\begin{array}{c}0.06 \\
(0.02)\end{array}$ & $\begin{array}{l}0.09 * * \\
(0.02)\end{array}$ & $\begin{array}{c}0.04 \\
(0.04)\end{array}$ \\
\hline Threshold (1) & $\begin{array}{l}-0.51 * * \\
(0.17)\end{array}$ & $\begin{array}{c}-0.49 * \\
(0.18)\end{array}$ & $\begin{array}{c}-0.41^{*} \\
(0.17)\end{array}$ & $\begin{array}{r}-0.10 \\
(0.35)\end{array}$ \\
\hline Threshold (2) & $\begin{array}{l}0.76 * * \\
(0.17)\end{array}$ & $\begin{array}{l}1.00 * * \\
(0.18)\end{array}$ & $\begin{array}{l}0.84 * * \\
(0.17)\end{array}$ & $\begin{array}{l}1.29 * * \\
(0.35)\end{array}$ \\
\hline Threshold (3) & $\begin{array}{l}1.22 * * \\
(0.18)\end{array}$ & $\begin{array}{l}1.50 * * \\
(0.19)\end{array}$ & $\begin{array}{l}1.14 * * \\
(0.18)\end{array}$ & $\begin{array}{l}1.62 * * \\
(0.35)\end{array}$ \\
\hline Threshold (4) & $\begin{array}{l}2.44 * * \\
(0.19)\end{array}$ & $\begin{array}{l}2.90 * * \\
(0.20)\end{array}$ & $\begin{array}{l}2.45^{* *} \\
(0.19)\end{array}$ & $\begin{array}{l}3.65^{* *} \\
(0.40)\end{array}$ \\
\hline $\begin{array}{l}\text { Cox and Snell Pseudo } R^{2} \\
N\end{array}$ & $\begin{array}{c}0.08 \\
1,444\end{array}$ & $\begin{array}{c}0.20 \\
1,373\end{array}$ & $\begin{array}{c}0.08 \\
1,446\end{array}$ & $\begin{array}{c}0.27 \\
1,381\end{array}$ \\
\hline
\end{tabular}

$* * p<0.01 ; * p<0.05$. Standard errors are in parentheses.

Source: British Election Study, 1997.

low end of the scale (i.e. not at all satisfied with democracy prior to the election to not very satisfied with democracy after the election). To compare their impact, we report a probability for the lowest and the highest level of each significant independent variable holding all other variables constant at their means. 


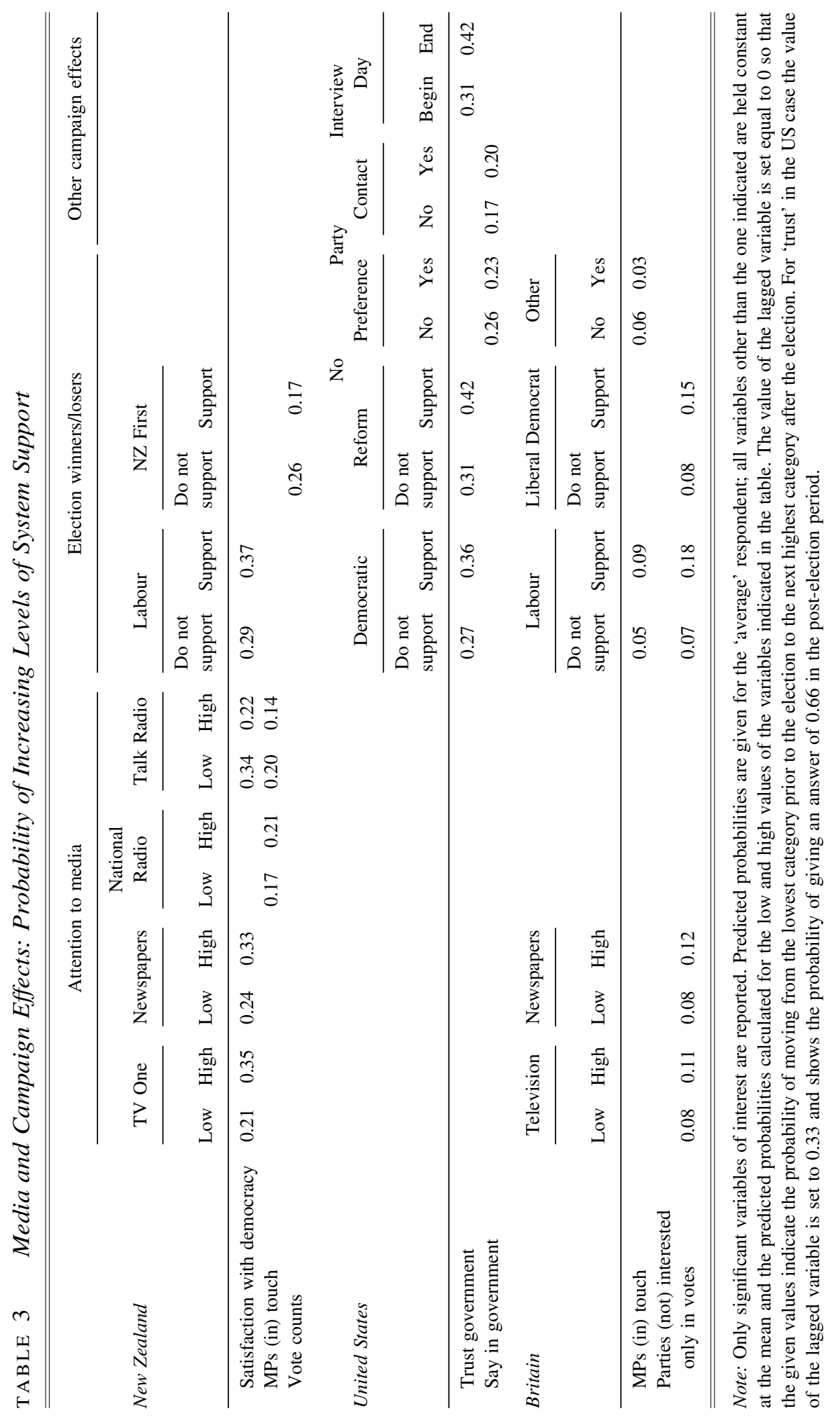


Looking first at the models predicting initial levels of system support, we see that media attention is significantly related to political attitudes in all three countries. In New Zealand, attention to newspapers and TV One, which is operated by a state-owned enterprise (TV $\mathrm{NZ}$ ), is positively related to satisfaction with democracy. Those paying attention to National Radio, a public broadcaster in the tradition of the BBC, were significantly more likely to believe that MPs are in touch. In the United States, attention to local television is positively related to trust in government.

Yet in both countries, attention to some media outlets is also negatively related to system support. In New Zealand, those paying attention to talk radio are less likely to be satisfied with democracy and those paying attention to TV 3, which is a commercial enterprise, are less likely to believe that MPs are in touch. In the United States, those who reported seeing campaign television advertisements have lower levels of system support. In Britain, attention to politics on television is positively associated with both indicators of system support, while the effect for newspapers is positive on one of the two indicators.

The impact of the media on changes in system support is evident in New Zealand and in Britain but not in the United States. In New Zealand, those paying attention to TV One and to the campaign in the newspapers were more likely to increase in satisfaction with democracy after the campaign than those who did not pay attention to those media outlets. Those paying attention to National Radio were also more likely to believe that MPs were in touch after the campaign. In Britain we see that those paying attention to news about politics on television and in newspapers became more likely to think that parties were interested in more than votes after the election. The probability of being in the second category for this question after the election for a respondent who was in the lowest category before the election is 0.08 if attention to television was low; if attention to television was high, the probability of moving up a category is 0.11 . A similar effect is seen for attention to newspapers.

Other media in New Zealand appear to have a demobilizing effect. However, these effects are limited to non-traditional media, talk radio, in New Zealand. Those who paid attention to talk radio became significantly less satisfied with democracy and significantly less likely to say that MPs were responsive. Looking at Table 3, we see that the probability of increasing from 'not being satisfied with democracy at all' to 'not being very satisfied' is 0.34 if someone paid little attention to talk radio, while the probability of increasing in satisfaction is 0.22 for someone who paid a lot of attention to talk radio. There is a similar difference in probability of saying MPs are not out of touch by levels of attention to talk radio. It is notable that we see a negative effect for talk radio in New Zealand but not in the United States. The nature of talk radio in New Zealand may explain this difference. There is only one call-in talk radio station in New Zealand compared to a much broader array of stations in the United States. The two most popular call-in shows on the New Zealand station are hosted by MPs. These shows tend to be highly critical of New Zealand politics. ${ }^{58}$ Therefore, it is reasonable that we see negative effects, due to the concentrated negative tone, in New Zealand but not in the United States. In Britain, attention to both newspapers and television produces significant increases on one of the items measuring system support. However, these effects are rather small.

While the relationship between attention to the media and system support varies across countries and media outlets, the impact of intended vote choice on system support is more

\footnotetext{
58 Judy McGregor, 'Talkback and the Art of "Yackety Yak" in Politics', in Judy McGregor, ed., Dangerous Democracy (Palmerston North, New Zealand: Dunmore Press, 1996), pp. 75-93.
} 
consistent across countries. In New Zealand, all of the parties to the left of the incumbent party intending to vote for the opposition are less satisfied with democracy than the incumbent party, National. Similar effects are evident in the United States and in Britain, with those supporting the opposition displaying lower levels of system support than those intending to vote for either the party in the White House (Democrats) or in government (Conservatives). In Britain, Labour supporters, however, are more positive on one of the two indicators of system support, suggesting that expectations about Labour's decisive victory may have contributed to greater support.

The change models indicate that electoral outcomes can lead to greater system support among the winners while depressing support for the losers. In New Zealand, Labour supporters had a significant increase in satisfaction with democracy after the Labour party won enough seats to form a coalition government. In Britain, Labour supporters were more likely to believe that MPs are in touch and that parties are not interested only in votes after the election. The increase in system support among Labour party supporters in both New Zealand and Britain seems more than reasonable given that the parties regained control of government after a long period in opposition. Similarly, Democratic party supporters became significantly more trusting after the Democratic party won the presidency for a second term. Electoral outcomes for the smaller parties, however, are not quite as clear. In Britain, the Liberal Democrats, who received fewer overall votes than in 1992 but nevertheless doubled their seat representation experienced an increase in efficacy. In the United States although the Reform party failed to receive any electoral votes in the 1996 presidential election, they nevertheless experienced an increase in political trust. During the campaign, both of the major parties attempted to reach out to Reform supporters. Perhaps in their case, winning and losing was less important than policy responsiveness. In New Zealand, supporters of the New Zealand First party, which had previously held the balance of power but now only managed to gain parliamentary representation, became less likely to believe their vote counted. Yet the supporters of Alliance, whose share of seats decreased but nevertheless entered into coalition, did not increase in system support.

There is limited evidence of other campaign effects. Given that party contact is an important factor in mobilizing the electorate, we should expect to see an increase in system support after the election for those contacted during the campaign. Since contact is measured after the election, we do not know whether respondents were contacted prior to their initial interview. Therefore, we focus our attention on the change model. The results indicate that at least in the United States there is support for our hypothesis. Those who report being contacted by a candidate or party were more likely to see an increase in efficacy than those who were not contacted. In New Zealand, however, party contact has no influence on changes in system support. The date of the interview is another indicator of campaign effects. The positive coefficient for trust in government in the United States shows that those interviewed earlier in the campaign had greater increases in trust indicating that trust increased throughout the campaign.

Overall, the multivariate models we present have weak predictive power. The explained variance in the non-lagged models never exceeds 10 per cent based on a pseudo $R^{2}$. This weak predictive power is common among models predicting trust and confidence. ${ }^{59}$ The fit of the model is considerably higher in the lagged models. Nevertheless, the results allow

59 Ola Listhaug and Matti Wiberg, 'Confidence in Political and Private Institutions', in Hans-Dieter Klingeman and Dieter Fuchs, eds, Citizens and the State (Oxford: Oxford University Press), pp. 298-322. 
us to draw conclusions about the relative impact of campaign and partisan effects on short-term changes in system support.

\section{CONCLUSION}

Our results show that aggregate shifts during a campaign tend to be small. However, there are significant changes in system support at the individual level that are related to politically relevant variables that occur during an election at the individual level, such as attention to the media and the electoral fortunes of a preferred party. Our results indicate that the campaign can cause short-term changes in efficacy and trust; however, at least some aspects of these indicators of trust and efficacy are firmly held attitudes. While the best predictor of post-election system support is pre-election level of system support, the indicators of system support used in this analysis are also subject to short-term forces. These short-term forces, when significant, tend to work in the expected way. Except for commercial television and talk radio in New Zealand, media coverage during the campaign, if it has any effect, has a mobilization effect. In most instances, the campaign has a positive influence on levels of trust and efficacy. While the content of the media has not been systematically linked to the survey data, the overall conclusion is that attention to the campaign in the media positively influences level of system support.

The panel design, including a control for political interest, is particularly good for detecting media effects. If attention to the different media were simply proxy variables for interest in politics we would not expect variation in the different media outlets found in the three countries. Additionally, we would not necessarily expect interest in politics to facilitate short-term change in system support but only initial levels of system support. There is also some evidence to suggest that the impact of media attention on system support depends on the particular medium. In all cases, newspaper reading had a positive effect on levels of system support. Indeed, the only media attention variables to have significant negative effects on level of system support are exposure to television advertisements (ANES) and attention to TV 3 in New Zealand. Overall, these findings suggest that outlets that are more serious (such as TV One in New Zealand) and more labour-intensive to consume (newspapers) are more likely to produce positive changes in levels of system support.

Election winners are indeed happier in all countries while most of the losers are less satisfied. Anderson and Guillory suggested that the effect of winning and losing depends on the nature of the political system. While their analysis is based on cross-sectional data, our panel design provides a far more rigorous test of the hypothesis. Moreover, by comparing attitudes before and after an election we measure more directly the effects of winning and losing. Anderson and Guillory's hypothesis leads us to expect that electoral outcomes would have more substantial effects in Britain than in either the United States or New Zealand. In Britain, the Labour party, having won a decisive victory in 1997, could govern on its own without sharing power. Yet in both the United States and New Zealand the winning party nevertheless had to share power with other parties. In the case of the United States, while the Democrats held the White House in 1996, they failed to gain control of either the House or the Senate. In New Zealand, while the Labour party won more seats than any other party in 1999, it was in no position to govern alone. Indeed, even after forming a coalition with the Alliance, the government failed to secure a majority of seats in parliament. While the fruits of victory may not appear to be as clear in the New Zealand case, their supporters experienced increases in support similar to those of Labour 
supporters in Britain. Similar increases are also evident for the Democratic party in the United States. These findings suggest that in the wake of a campaign, electoral outcomes may be more important to voters than governing.

Evaluations of policy outputs also influence static levels of system support but do not contribute to short-term changes over the course of the campaign (except in one case). These results suggest that we should consider the factors that influence system support to exist along a continuum from long-term to short-term factors. For example, the electoral system is a long-term factor not likely to change or change often, whereas the state of the economy is more variable but not as variable as media coverage during an election campaign. In turn, the concept of system support is multi-dimensional and subject to different influences (possibly at different times during the election cycle as well).

While we do not address the source of long-term decline in some indicators of system support, we do see that in the short term, system support can be influenced both by attention to different media and to being an election winner or loser. We see systematic changes in levels of system support consistent with expectations over the relatively short time span of an election campaign. These results suggest that the ability of elections to mobilize system support among the citizenry is limited to election winners and to those paying attention to at least some media coverage (but not talk radio in New Zealand). For those who argue that citizens are becoming more critical of the way democratic institutions work but not less supportive of democracy, our results suggest that responses to questions of system support can depend on factors other than evaluations of institutional performance. These short-term sources of change, such as media attention and supporting a winning party, show that election campaigns can make citizens less critical and more supportive.

Our results can also be examined in terms of the meaning and measurement of system support. We have used a variety of questions to indicate various dimensions of support for the political system. Our results indicate that campaigns can lead to positive changes in levels of trust (in New Zealand and the United States) and satisfaction with democracy (in New Zealand). These questions have been used to measure overall regime support. Therefore, campaigns can mobilize system support. However, some of the largest (both positive and negative) changes occur for winners and losers suggesting that these indicators besides tapping diffuse support are also tapping more immediate support of the election outcome itself. We should not assume, however, that this presents a measurement problem for the indicators of regime support. After all, we should expect some relationship between indicators of diffuse and specific support. ${ }^{60}$

Finally, while our results show the potential for the campaign to have both a mobilizing and demobilizing impact on system support, the question remains as to whether the changes are long lived or whether they dissipate weeks or months after the election. Given our design, we cannot be certain that the positive changes in levels of system support experienced during an election campaign are sustained. The overall decline in system support indicates that these short-term fluctuations, particularly mobilization effects, are not likely to be long lived. This suggestion points to the need for further study on the timing of system support questions and its influence on overall levels of system support.

${ }^{60}$ We would like to thank an anonymous reviewer for making this point. 
APPENDIX: QUESTION WORDING AND VARIABLE CODING

New Zealand Election Study 1999

System support: Satisfied with Democracy: How satisfied are you with the way democracy works in New Zealand?

$0=$ Not at all satisfied; $0.33=$ Not very satisfied; $0.66=$ Fairly satisfied; $1=$ Very satisfied.

Do you agree or disagree with the following statements? MPs are out of touch. $1=$ Disagree; $0.5=$ Neutral; $0=$ Agree.

My vote counts in elections. $1=$ Agree; $0.5=$ Neutral; $0=$ Disagree

Media Attention: How much did you pay attention to the following during the campaign: TV One, TV Three, Newspapers, National Radio, Talk radio? $1=$ Often; $0.66=$ Sometimes; $0.33=$ Hardly ever; $0=$ Never. (Post-election.)

Contact: Did you receive a visit or telephone call from any of the following parties: National, Labour, New Zealand First, Alliance, Greens, ACT? $1=$ Yes; $0=$ No.

Date of Interview: Number of days from start of pre-election interviewing.

Economy: Has the economy gotten better or worse over the past 12 months? $1=$ Better; $0.5=$ Stayed the same; $0=$ Worse. (Pre-election.)

Maori: $1=$ Identified self as Maori; $0=$ Otherwise.

\section{American National Election Study, 1996}

System support: How much of the time can you trust what government does? $1=$ Almost all of the time; $0.5=$ Only some of the time; $0=$ Almost never. (Pre-election and Post-election.)

Do you agree or disagree with the following statement? People like me have no say about what government does. $1=$ Agree strongly; $0.75=$ Agree; $0.5=$ Neither agree or disagree; $0.25=$ Disagree; $0=$ Disagree strongly. (Pre-election and Post-election.)

Media Attention: How much attention did you pay to the following during the campaign: National TV, Local TV, Newspapers, talk radio? $1=$ A great deal; $0.75=$ Quite a bit; $0.5=$ Some; $0.25=$ A little; $0=$ None. (Post-election.)

Did you see any party or candidate TV advertisements during the campaign? $1=$ Yes; $0=$ No.

Contact: Were you contacted by a candidate or party during the campaign? $1=$ Yes; $0=$ No. (Post-election.)

Economy: Has the economy gotten better or worse over the last 12 months? $1=$ Much better; $0.75=$ Better; $0.5=$ Neutral; $0.25=$ Worse; $0=$ Much Worse. (Pre-election.)

\section{British Election Study, 1997}

System support: How much do you agree or disagree with the following statements: (1) Generally speaking those we elect as MPs lose touch with people pretty quickly. (2) Parties are only interested in people's votes, not in their opinions.

$1=$ Disagree strongly; $0.75=$ Disagree; $0.5=$ Neutral; $0.25=$ Agree; $0=$ Agree strongly .

Media Attention: Combined responses to two questions: Did you read any daily newspaper (or watch any TV news) yesterday? If yes, how much attention did you pay to political stories? $1=\mathrm{A}$ great deal; $0.8=$ Quite a bit, Some; $0.6=$ A little; $0.4=$ None; $0.2=$ Saw no political stories; $0=$ Did not watch TV/Read Newspaper. 


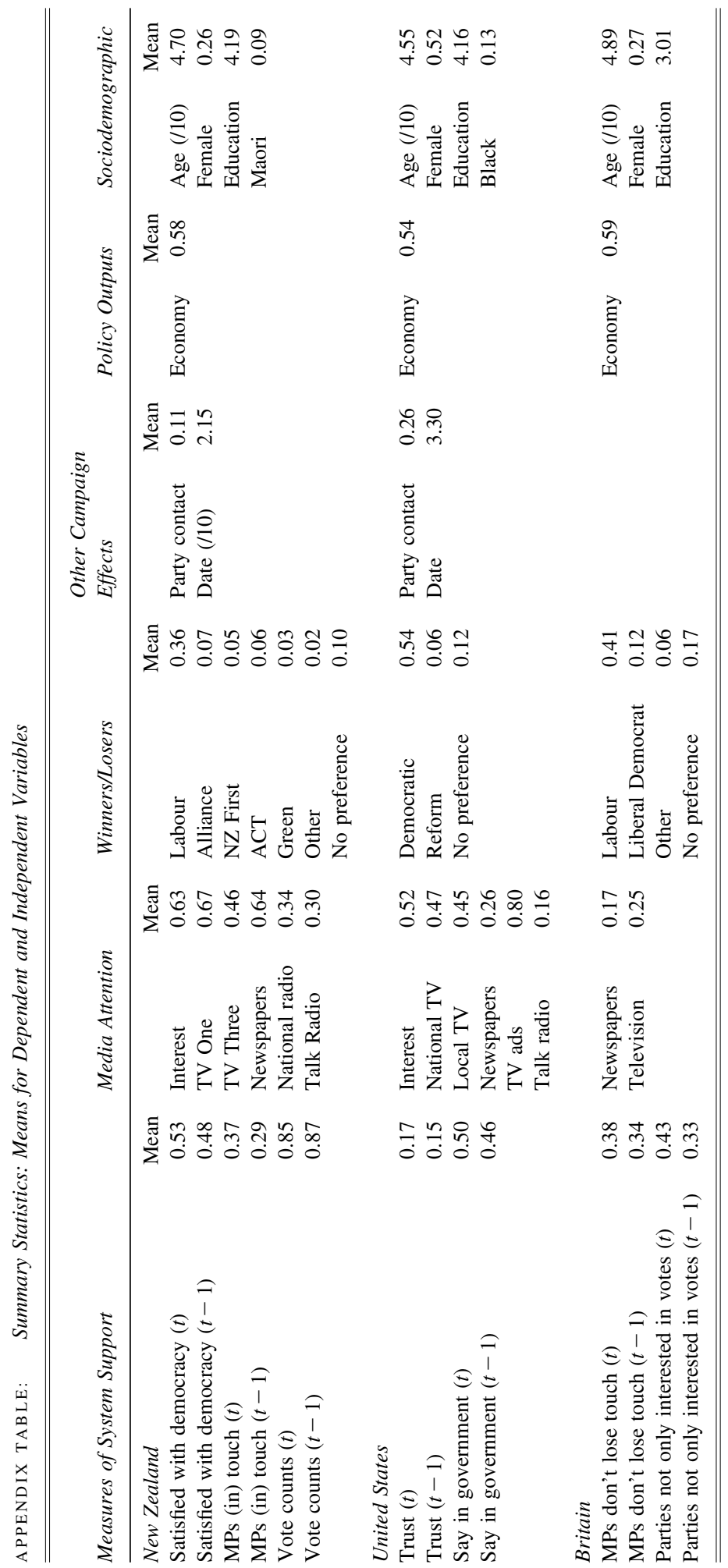


Economy: Has Great Britain's economy gotten stronger or weaker over the last 12 months? $1=$ Got a lot stronger; $0.75=$ Got a little stronger; $0.5=$ Stayed about the same; $0.25=$ Got a little weaker; $0=$ Got a lot weaker.

\section{All Studies}

Winners and Losers: Intended party vote measure during pre-election survey.

Age: Age in 10-year bands.

Female: $1=$ Female; $0=$ Male.

Education: highest educational qualification. 
